\title{
EDITORIAL
}

\section{Educação, Ciência e Democracia}

Há um consenso de que o Ensino de Matemática e das Ciências desempenha um papel crucial no desenvolvimento do país. Infelizmente, em muitos casos, trata-se de um consenso meramente retórico. $\mathrm{O}$ apoio recebido, nas várias instâncias governamentais (ministérios, secretarias, órgãos financiadores, etc.), expresso em palavras apologéticas e altissonantes, não vem acompanhado, em grande parte das vezes, de políticas públicas suficientemente adequadas que confiram ao Ensino da Matemática e das Ciências a prioridade que este merece e requer.

As mazelas históricas de nosso sistema educacional já foram identificadas há algumas décadas. O famoso Manifesto dos Educadores Pioneiros da Escola Nova de 1932 declara, já no seu primeiro parágrafo, algo que expresso em palavras hodiernas tem o seguinte teor: "Dentre todos os fatores, é a educação o mais prioritário e essencial deles para agregar valor ao nosso desenvolvimento". Trata-se da Educação no sentido lato do termo; evidentemente, e como dimensão importante desta, trata-se da Educação Científica. O que foi escrito em 1932 talvez seja, hoje, ainda mais atual e urgente. Vivemos em um mundo disseminado de produtos científicos e tecnológicos e, assim, cada vez mais a Educação Científica assume um papel de imprescindível relevância nas nossas vidas.

Guardadas as devidas e importantes diferenças e falando a grosso modo, este tem sido o entendimento de todos os que falam em inclusão social, alfabetização científica, divulgação científica, popularização da C\&T, etc. A tudo isso subjaz a tese segundo a qual o conhecimento pela Educação Científica se constitui em um dos fatores precípuos, senão o mais relevante, a prover a inclusão social.

Desnecessário dizer que tudo isso é urgente, pois é necessário superar, ou pelo menos amenizar significativamente, a enorme carência de professores de Matemática e das Ciências - notadamente de Física - no Ensino Médio. Esse é, sem dúvida, um dos grandes obstáculos ao nosso desenvolvimento.

Para tal, são necessárias políticas públicas inclusivas cujos processos não devem conhecer soluções de continuidade. Essas políticas devem levar em conta um pacto federativo saudável e também devem incluir esforços a serem envidados para integrar as diversas regiões do país. Desse modo, faz-se necessária a adoção concreta de políticas públicas de Estado e não apenas de políticas efêmeras e desarticuladas deste ou daquele governo de ocasião. 
Às complexas relações envolvendo C\&T e Sociedade, devem ser incorporadas, enquanto dimensões imprescindíveis, - e não enquanto meras perfumarias e externalidades supérfluas - a Ética e o Ambiente.

Queremos uma Educação Científica que seja capaz de prover o entusiasmo e a procura das autonomias, política e intelectual, dos jovens estudantes. Exatamente por isso, ao entusiasmarmos os nossos jovens e, conseqüentemente, ao fazermos a apologia da beleza e da necessidade da atividade científica para o nosso desenvolvimento, também temos o dever ético de alertá-los para o outro lado da questão.

É necessário dizer que, notadamente nos países científica e tecnologicamente mais desenvolvidos, setores significativos das comunidades científicas têm relações espúrias e bastante duvidosas com as grandes corporações multinacionais, em detrimento mesmo da paz, da saúde pública, da ética e do ambiente. Essas corporações, que constituem mega-poderes, têm interesses de mercado que são, muitas vezes, contrários ao sadio desenvolvimento social e, não raro, se utilizam da venalidade de muitos membros das comunidades científicas para legitimarem os seus interesses. Desnecessário dizer o quanto isso representa de perigo para a democracia, para o pluralismo e para a degradação dos padrões éticos da atividade científica. Ao reivindicarmos em prol de altos padrões éticos e cognitivos, estamos defendendo uma ciência sã, que se contrapõe a essa iniqüidade. As sociedades civis planetárias devem estar atentas e atuantes quanto a este perigo.

Afinal, se quisermos uma Educação Científica não-bancária (no sentido da crítica de Paulo Freire), que se contraponha a uma educação meramente indutiva, não-criativa e repetitiva (no sentido da crítica de Popper às cabeças que são apenas baldes mentais), haveremos obrigatoriamente de estimular a emergência de cabeças autônomas e independentes.

\author{
Jenner Barretto Bastos Filho \\ Instituto de Física - UFAL \\ Maceió - AL
}

